\title{
1. The multinational enterprise, industrial development and policy: an introduction to the primary themes of this volume
}

The essays in this book, part or all of which were originally published between 1998 and 2004, set out the views and opinions of the authors on three main topics. Each of these is a key ingredient in the current debate on the contribution of multinational enterprises (MNE) to economic development in an increasingly globalizing, knowledge-intensive and alliance-based world economy.

The first topic embraces some of the implications of the increasing role played by cross-border trade and foreign direct investment (FDI) for the competitiveness and structural transformation of developing countries. Chapter 2 first offers a brief review of the changing world economic scenario over the past two decades, and how this has affected the locational advantages of developing countries, as perceived by foreign investors, and the ownership advantages of foreign MNEs, as perceived by host countries. In doing so, it emphasizes the need for host governments continually to upgrade the institutional infrastructure underpinning their indigenous resources and capabilities, and their economic policies, if they wish to retain and/or raise their bargaining strengths, and to avoid 'falling behind' in the race to attract foreign investment. We make five main points. First, economic globalization has affected regions and countries unevenly and this is reflected in the configuration of MNE activity. Second, the failure of most of the developing world to catch up is associated with the inadequate level of domestic created assets and the inefficiency of local firms. Third, an important means by which to upgrade their competitiveness has been the importation of technology, skills and organizational capabilities both via FDI and by collaborative arrangements. Fourth, the conditions for catch up are also necessary (but insufficient) conditions to attract FDI. Fifth, there is a threshold level of created assets which determine the ability of domestic

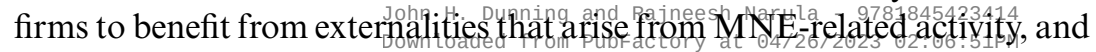


a threshold level of created assets and industry clusters is also necessary as location advantages to attract such activity in the first place.

Chapter 3 takes these themes and pays more specific attention to the changing economic relationships between MNEs and host developing countries at different stages in the latter's development. We build upon our earlier work (see Dunning and Narula, 1996; Narula, 1996) on the investment development path (IDP) and further develop our understanding of the interactive nature of economic development and foreign direct investment, in this instance focusing on the challenges facing developing countries. We add to our understanding of the intertwined and interdependent nature of development and MNEs by highlighting how motives of investment change with the stages of the IDP. We emphasize that these relationships have been dramatically affected by new technologies, and the renaissance of market-based capitalism; and that, consequentially, host governments have had to re-evaluate not only their micro-management strategies, but also their industrial development options.

The chapter also emphasizes the contextual characteristics of FDI, and the differences in the bargaining power and strategies of the more industrialized vis-à-vis the poorer developing countries. After all, globalization has changed the economic realities of all parties. First, the competences of MNEs are becoming increasingly mobile and knowledge-intensive. MNEs thus give more attention to the availability and quality of the created assets of alternative locations. Second, among developing countries there are now considerable differences between the 'catching up' countries (for example, newly industrializing countries - NICs) and 'falling behind', less-developed countries (LDCs). These developments have helped change the opportunity sets of both MNEs and host countries. FDI-based development strategies are now commonplace among LDCs, but there is also increased competition for the 'right' kinds of investment. In general, the balance in bargaining power has shifted in favour of the MNE, and LDCs increasingly need to provide unique, non-replicable created assets to maintain a successful FDIassisted development strategy.

In Chapter 4 we extend the principles and predictions of the investment development path (IDP), which has been subject to extensive empirical testing over the past decade, to do two things. The first is to trace the relationship between trade, FDI and economic development; the second is to examine the medium-term impact of both trade and FDI on the changing industrial structure of developing countries. Data from Korea and Taiwan for a 30-year period point to the increased richness of the IDP once these additional variables are taken into account.

The final chapter of Part I considers the impact of regional integration

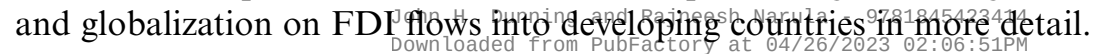


Although FDI has significant influence on economic development, much of the work on regional integration (RI) has focused on trade effects. Chapter 5 seeks to examine the effect of regional integration on MNE strategies while acknowledging other globalization-related developments. In particular, we examine the ways in which various regional integration schemes have affected the strategies of different kinds of MNEs and their subsidiaries à propos their value-added activities in developing countries. The chapter distinguishes between two groups of developing countries: the least developed, with little or no domestic industrial capacity, and the rest, with an intermediate level of capacity. We examine MNE strategies in developing countries in four scenarios: (1) in a non-RI, pre-liberalized environment, (2) with RI in a pre-liberalized environment, (3) in a non-RI, post-liberalization scenario, (4) RI in a post-liberalization scenario. We also distinguish between least developed countries (LDCs), and intermediate developing countries, within North-South and South-South RI.

Liberalization and a shift in policy orientation have had a greater effect on MNE strategies than integration. Globalization of MNE activity and liberalization has led to a downgrading of MNE activity in most LDCs. Much of the gains in FDI flows have been a result of redistribution, associated with privatization. Countries with a threshold level of domestic capability and more efficient institutions have benefited from increases in the quality of FDI. RI schemes have reinforced these trends, benefiting those countries that have a viable domestic sector, and have created the appropriate multilateral institutions to exploit cross-border efficiencies. In general, South-South RI in a post-liberalized world has had limited benefits for LDCs relative to intermediate developing countries. RI schemes need to be seen as an opportunity to respond gradually to globalization in a controlled and stepwise manner, and not as an alternative to multilateralism.

The second part of the volume addresses three main themes. The first is the growing importance of innovatory activities of firms (and in particular R\&D) in promoting economic development and industrial restructuring; and also the role of FDI in furthering this goal. The second is the emergence of cross-border strategic alliances as a means of gaining access by firms domiciled in one country to foreign-based R\&D and innovatory systems. The third is the increasingly significant role of national governments in promoting the intellectual capital of their indigenous resources and capabilities, and of inter-firm collaborative alliances.

Chapter 6 first explains the rationale behind the rapid growth and the deepening of cross-border technology-based collaborative ventures over the past two or three decades and how this has been affected by the disinternalization of the value-added chain of many MNEs, and the

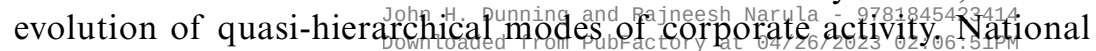


motor, electronics and garment industries, are best undertaken by SMEs. The second is that, owing to a fall in many spatial transaction costs, the growing opportunities for networking, and the financial and other assistance provided by governments (both in developed and developing countries) for 'seed' and innovatory activities best performed by SMEs, such firms are playing an increasingly pivotal role in the new international division of labour. This state of affairs has altered the raison d'etre of the SME. On the one hand, SMEs have always sought to specialize in niches, given their limited resources. Consequently, their role as specialized suppliers to large firms has increased. On the other hand, the cross-fertilization of technologies has meant that they also need to span several competences. As will be seen, Chapter 9 illustrates these points by examining two important concurrent dynamics. The first dynamic pertains to the various types of SMEs and how the industrial structure and external environment influence their collaborative activity. The second dynamic is associated with the evolution of technologies, technological paradigms and trajectories. We explain how different types of SMEs tend to dominate the industry structure at a given stage of the evolution of a given core technology. Evidence is presented from a survey on the collaborative activities of one particular form of the SME (the 'stand-alone' SME) in the electronics hardware sector. The analysis is based on in-depth interviews and questionnaire surveys of over a hundred European technology firms and attempts to explain the reasons for the preference of one type of collaboration over another, and the limitations of collaboration as an alternative to in-house R\&D.

The three chapters in Part III focus on two main issues. The first describes some of the changing competitive, or ownership (O), advantages of firms and the locational (L) advantages of countries. More specifically, Chapter 9 avers that, alongside the capabilities of MNEs to create and efficiently deploy new knowledge, and those of countries to promote the innovatory capabilities of their indigenous resources in line with their (perceived) long-term dynamic competitive advantage, more attention needs to be given to the institutional framework undergirding these capabilities, and particularly the quality of the relational assets possessed or exploited by both individuals and organizations. Such assets, as Chapter 9 describes, may be either private or socially owned, they may be created or acquired as a result of intraorganizational or interorganizational transactions. In turn, such transactions may be conducted at a dyadic or network level. This chapter (part of which has not been published before) is the first attempt to place these issues firmly in the context of the mainstream explanations of the economic determinants of MNE activity.

Chapters 10 and 11 reproduce the contents of two public lectures given

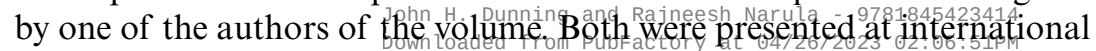


investment fairs - one in Seoul, Korea in 1999, and the other in Xiamen, China in 2002. The subject of both lectures was 'Upgrading the competitiveness of indigenous firms and resources by FDI'; and more particularly, the subject was to describe and evaluate both the forms and the structure of such upgrading. The Seoul lecture was given shortly after the end of the Asian crisis, and it focused primarily on the lessons that Asian businesses and governments might be usefully learning from their US counterparts.

The thoughts expressed in Chapter 11 were prompted by China's accession to the World Trade Organisation (WTO). In this chapter, we pay detailed attention to the specific contributions FDI might make to China's bid to become more competitive as a global player and to the policies and strategies which the Chinese government may consider deploying if it wishes to ensure that such investment best promotes the host countries' structural transformation and its long-term comparative advantage.

Each of the essays in this volume, then, touches upon critical issues now facing the global economy, and of developing countries in particular. We would emphasize three main conclusions. The first is that MNEs have played and are likely to continue to play an important role in the structural upgrading of these countries. However, the extent and pattern of these benefits is strongly dependent on the form of economic and social development desired by the host countries, and on the policies of host governments in pursuing these goals. Although not the only means available, spillovers from FDI are regarded as one of the most practical and efficient means by which industrial development and upgrading can be promoted. While the potential for MNErelated spillovers is clear, as are the opportunities for industrial upgrading therefrom, it is increasingly acknowledged that the nature, level and extent of the benefits vary considerably. Furthermore, it is important to realize that MNEs are not in the business of economic development. Even where they do seek to transfer knowledge, they prefer to use technologies that are suited (first and foremost) to their own needs, and the purposes for which they have made the investment. MNEs do not make their proprietary assets available at the whims of governments; rather they tailor their investment decisions to the existing market needs, and the relative quality of location advantages (especially skills and capabilities in which the domestic economy has a comparative advantage). Once the decision to enter a given market through FDI is taken, the kinds of activity and the level of competence of the subsidiary are also co-determined by the nature of the location advantages of the host location. That is to say, while MNE internal factors such as their internationalization strategy, the role of the new location in their global portfolio of subsidiaries and the motivation of their investment are pivotal in the structure of their investment, they are dependent on the

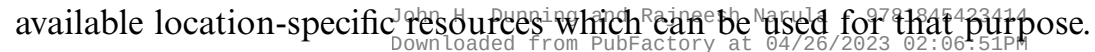


MNEs and unrestrained flows of inward FDI may well lead to an increase in productivity and exports, but they do not necessarily result in increased competitiveness of the domestic sector or increased industrial capacity, which ultimately determines economic growth in the long run. FDI per se does not provide growth opportunities unless a domestic industrial sector exists which has the necessary technological capacity to profit from the externalities that derive from MNE activity. To put it simply, FDI is not a sine qua non for development (Portelli and Narula, 2004). ${ }^{1}$

The second conclusion is that cross-border strategic alliances are becoming an increasingly important modality by which both firms and countries can enhance their respective $\mathrm{O}$ - and L-specific advantages; and that governments need to reappraise, and where appropriate enhance, the innovatory, entrepreneurial and institutional infrastructure to reap the maximum gains from these cooperative ventures. After all, every firm is idiosyncratic in nature, and has distinct technological trajectories. Cooperative arrangements, difficult at the best of times, are made even more complex by the nature of cross-border cooperation. Cooperation between firms of different and distinct technological competences requires some common ground.

Furthermore, the nature of technology development and R\&D adds a unique twist. In most cases, these activities are not affected by tariff and non-tariff barriers, since they involve the development and implementation of knowledge, which is highly tacit and embodied in highly skilled personnel.

It is worth noting that globalization is a more powerful force than economic integration within any one region. The fact is that there is a growing convergence of income and consumption patterns, as well as types of technologies used, and this is occurring across all countries within the Triad (North America, Japan and Western Europe). In general, firms are competing and growing in order to compete with other firms in the same industry, regardless of their nationality. The same is true of alliances, where firms are interested in partnering other firms in the same industry, regardless of their nationality, but on their relative qualities as a partner, and the nature of their technological competitiveness.

Globalization has affected the need of firms to collaborate, in that firms now seek opportunities to cooperate, rather than identify situations where they can achieve majority control. In addition, the increasing similarity of technologies across countries and cross-fertilization of technology between sectors, coupled with the increasing costs and risks associated with innovation, has led to firms utilizing alliances as a 'first-best' option (see Narula, 2003, for a discussion). Alliances, as with most forms of innovative

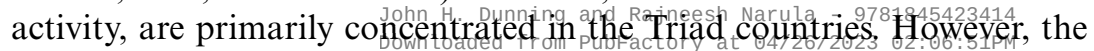


propensity of firms of a given nationality to engage in alliances varies according to the characteristics of the country. This is because small and technologically less advanced countries tend to be focused in fewer sectors than large countries, owing, inter alia, to the differences in economic structure and demand.

Government intervention to promote R\&D alliances does not, contrary to popular belief, lead to an increase in the overall level of R\&D activity in a given location. It should be noted that $R \& D$ alliances are even more footloose than traditional majority-owned production or R\&D activities, nor, it must be stressed, do R\&D alliances provide significant levels of spillovers to the host economies where they might be located. Funds invested in joint research by governments are notoriously hard to track down, in terms of their application, both in a geographic and a technical (that is, project-specific) sense. Furthermore, firms are more interested in establishing themselves near centres of agglomeration, regardless of where these might be located (Narula, 2003). This indicates a very real danger of entering an incentive war, with so many countries willing to subsidize $R \& D$, and with so few obvious spillovers therefrom.

The third conclusion is that globalization and technological advances are reconfiguring the ingredients of the competitiveness of firms and nation states and, in particular, are emphasizing the increasingly important role of both private and social institutions (à la Douglass North) as determinants of the success of corporations and of the economic development of societies. Incentive structures and enforcement mechanisms both constrain and predetermine what firms and governments can and cannot do. Institutional reform may encourage economic restructuring of MNE activity as it is now doing in Central and Eastern Europe. New paradigms of economic development are fully embracing institutions within their purview (Dunning 2004).

At the same time, not only does institutional change usually lag behind technological et al. changes, it sometimes is resistant to such changes. All too frequently, economic units will prefer to maintain existing institutions with competitors, customers and external organizations, produce similar products and remain in similar locations, unless an external force is applied (Narula, 2003). That is, they prefer to maintain their current state of equilibrium, if it does not threaten their survival. When an external force is applied - be it because of a new technology, change in the industrial or market structure, legal and governmental fiat - economic units will seek to modify their routines to accommodate this change to create a new 'equilibrium' preferably in close proximity to their existing routines. Firms loathe radical change. Radical change is costly and highly risky and, because routines and institutions develop slowly, radical change that is undertaken rapidly is even more risky. 
However, every subsequent change becomes less costly, because the knowledge of developing new markets, technologies and institutions can be applied to future scenarios. That is, the economic unit has acquired the 'technologies of learning' and these can be applied, ceteris paribus, to other situations. A US firm's experience of developing its first European affiliate in (say) Germany makes it easier to enter other similar markets such as Denmark and the Netherlands. This line of reasoning has been demonstrated time and time again for firms of all nationalities. ${ }^{2}$ The importance of institutions and institution building cannot be overemphasized. If the appropriate institutions and organizations are absent or underdeveloped, economic actors within the system will be unable to absorb and efficiently utilize knowledge that may be made available to them.

\section{NOTES}

1. See also special issue of the European Journal of Development Research, 2004, vol. 16, issue 3, edited by Sanjaya Lall and Rajneesh Narula.

2. See, for example, Johanson and Vahlne, 1977; Hagedoorn and Narula, 2001; Hogenbirk, 2002.

\section{REFERENCES}

Dunning, J.H. (2004), 'Towards a new paradigm of development: implications for the determinants of international business activity', paper presented to UK Chapter of the Academy of International Business, April.

Dunning, J.H., and R. Narula (1996), 'The investment development path revisited: some emerging issues', in J.H. Dunning and R. Narula (eds), Foreign Direct Investment and Governments: Catalysts for Economic Restructuring, London: Routledge.

Hagedoorn, J., and R. Narula (2001), 'Evolutionary understanding of corporate foreign investment behaviour: US foreign direct investment in Europe', in R. Narula (ed.), International Trade, Investment in a Globalising World, New York: Pergamon.

Hogenbirk, A. (2002), Determinants of Inward Foreign Direct Investment: The Case of the Netherlands, Maastricht: Datawyse.

Johanson, J., and J. Vahlne (1977), 'The internationalization process of the firm - a model of knowledge development and increasing foreign market commitments', Journal of International Business Studies, 8 (1), 23-32.

Narula, R. (1996), Multinational Investment and Economic Structure, London: Routledge.

Narula, R. (2003) Globalisation and Technology, Cambridge: Polity Press.

Portelli, B., and R. Narula (2004), 'FDI through acquisitions and implications for industrial upgrading: case evidence from Tanzania', MERIT Research Memorandum 2004-011. 
John H. Dunning and Rajneesh Narula - 9781845423414

Downloaded from PubFactory at 04/26/2023 $02: 06: 51 \mathrm{PM}$ 